\title{
A comprehensive review of disputes prevention and resolution in construction projects
}

\author{
Wesam S. Alaloul ${ }^{1, *}$, Mohammed W. Hasaniyah ${ }^{2}$, and Bassam A. Tayeh ${ }^{2}$ \\ ${ }^{1}$ Civil and Environmental Engineering Department, Universiti Teknologi PETRONAS, Seri Iskandar, Malaysia \\ ${ }^{2}$ Civil Engineering Department, Faculty of Engineering, Islamic University of Gaza, Gaza, Palestine
}

\begin{abstract}
The construction industry is complex, fragmented, dynamic and involves many parties in an adversarial relationship. This makes disputes almost inevitable in any construction project. This paper aims to provide a comprehensive review of the adopted methodologies in resolving disputes that arise in the construction projects. The paper evaluates and classifies the different methods of disputes resolution. A comparison was conducted between the advantages and disadvantages of each method. The paper distinguishes between the traditional method of disputes resolution; litigation and Alternative Dispute Resolution (ADR) methods such as arbitration, mediation, med/arb, mini-trial and dispute review board. In conclusion there is no best way to solve all kind of disputes in construction projects, however, a general step by step process of how disputes should be addressed is finally presented.
\end{abstract}

\section{Introduction}

The complexity of construction projects is continuously increasing which increases the complication of contracts and the disputes probability that might arise at any stage in the project lifecycle [1]. Therefore, disputes are almost unavoidable in construction projects [2]. It is normally trusted that owners' initial choices regarding the selection of delivery methods, procurement methods, and contract types influence the recurrence and seriousness of project disputes $[3,4]$. In this context, the construction projects are fertile seedbed for disputes. Plenty of factors contribute to the development of disputes in construction projects, among these are: adversarial nature of contracts; poor communication between the parties, ineffective communication on site, inability to understand terms of contract, different expectations of the parties, fragmented nature of the industry, improper contractual documentation, tender systems and government policy on tendering, the inability or reluctance to pay, and unforeseen effect of third party interests [5]. Each factor can ultimately disrupt the work, halt the communication between the different parties in the project, and lead to a tedious process in resolving the disputes that might develop between them $[6,7]$.

The relationship formed between contractual parties is complicated and requires time and resources coordination in the project to be successful, which is the goal of all the parties involved. Success is defined as a project completed within the original time span and allocated budget. However, success is not always achieved as the contractual parties' desire. One of the major factors of unsuccessful projects is the adversarial nature between the project parties which leads to the development of disputes. Another important factor is the methodologies used for resolving these disputes when they come to the surface $[8,9]$.

The purpose of this paper is to review the present methodologies used in the construction projects for preventing and resolving disputes. The paper aims to present the advantages and disadvantages of the methods and to determine which one can work better for a particular situation [10].

\section{Disputes definition}

In the construction industry, because of contrasts in perceptions among the participants of the projects, conflicts are inescapable. In the event that conflicts are not all probably managed, they rapidly transform into disputes. Differences between conflict and dispute are not agreed upon among construction experts which lead to the interchangeable use of the two terms [11]. Collins dictionary defines conflict as a serious disagreement and argument about important issues [12]. It is also defined as a discrepancy between at least two independent parties who perceive incompatible goals, scare resources, and interference from other [13]. A dispute, on the other hand, is defined as any contract question or controversy that must be settled beyond the jobsite management [14]. Conflicts exist when there is a discrepancy of interest which can be managed, possibly to the point of preventing

* Corresponding author: wesamalaloul@uttp.edu.my 
them to become disputes. Disputes require resolution and therefore, are associated with distinct justiciable issues. The resolution process may lend itself to third-party intervention $[15,16]$. If disputes are not resolved, they usually lead to a claim. In fact, $10-30 \%$ of construction projects experience serious disputes, and in one in four disputes, claims are ultimately filed $[17,18]$. Claims could also be a precursor to disputes rather than being a product of disputes. The dispute is not because a claim has been submitted but because it has not been admitted [19, 20].

\section{Traditional dispute resolution method: litigation}

Litigation is simply the act of a lawsuit. It is the most traditional form to resolve disputes. Litigation in construction is defined as a process of engaging in or contesting legal action in court as a means of resolving a dispute. The court is able to enforce or determine one party's rights or obligations. In litigation, the plaintiff files a suit to the court believing that the defendant's actions were wrong. However, both parties generally feel distressed about going to trial since it usually includes an extended time of disclosure, its procedures tend to be inflexible and its constantly being delayed [21, 22]. Once the litigation process is started, the decisions become in the hand of a judge or jury who may have little knowledge about construction projects [22].

While there are several Alternative Dispute Resolution (ADR) methods, going to trial is still one of the most common methods to resolve disputes within the construction industry [23]. Even though litigation is considered the last resort method of dispute resolution, sometimes it is unavoidable [24]. Litigation is considered the costliest dispute resolution method, however, sometimes avoiding litigation could be more expensive than engaging in it $[25,26]$. Moreover, many construction experts believe that litigation is not a suitable tool for resolving disputes in the construction industry. One reason for that is, the construction projects are built upon good relationships between its parties and any future work generally depends on the present and previous relations between the parties. Attorneys handling litigation are trained to be adversarial and to use any strategy to win. Whether the relationship between the parties is maintained or not is of secondary importance attorneys [21, 27, 28]. This particular reason makes litigation an unfavourable process to contractors since it damages sustainable relationships with the owner, architects, engineers, and other participants in construction projects. Another important factor for avoiding litigation is the complexity of technical and financial matters associated with construction disputes which will probably elongate and complicate the trial process [17]. Moreover, litigation is not preferred when secrecy and privacy are important. Litigation is generally open to the public and the documents filed to the case and court proceeding transcripts could be available to media and the public [27]. Litigation is effective when the disputes are originated based on legal issues that have been dealt with previously in courtrooms. Whenever the outcomes of litigation are almost certain, and it is expected that litigation will not be a time-consuming process, litigation is the best choice to resolve disputes and regain rights. Subsequently, going to court may enable a party to accomplish its objectives, while settling the manner by means of another procedure may not lead to objectives achievement [29, 30]. Commonly, litigation is used to resolve serious disputes that arise in complex projects [31].

\section{Alternative Dispute Resolution (ADR) methods}

\subsection{Negotiation}

Negotiation is certainly a universal method for disputes resolution. The objective of this method is that a dispute should be settled immediately and efficiently in terms of time management, costs and preservation the relationships. This method is considered the simplest method, but it highly depends on the intentions of the disputants and their desire to put the issues behind them. Stipulating that negotiations were not successful, then other methods are available [32].

\subsection{Arbitration}

Arbitration is a process wherein opposing parties submit their dispute or conflict for a binding determination by one or more third parties. It was developed as a faster, more cost-effective and less formal alternative to litigation. Also, arbitration attempts to ensure that the law is followed wherever possible and a friendly language is used among disputants, although this is not always the case. Unlike litigation, the use of arbitration requires the agreement of both dispute parties. Arbitration has been used in construction contracts since 1871. Ever since, the use of arbitration has spread globally and nowadays it is commonly used in the construction industry $[33,34]$.

The procedures of arbitration require firstly the selection of the arbitrator or the arbitration panel. There are usually specialized organizations, for example in the United States the American Arbitration Association (AAA) provides a list of qualified arbitrators. A list of selected arbitrators is sent to both parties of dispute; they should review and agree on the selection of arbitrators from the sent list. Then, an arbitration hearing is scheduled in accordance with the arbitrator and the disputants [35]. Any documents, testimonies, or pieces of evidence are presented to arbitrators by the attorneys of each party. Similar to litigation, arbitrators have complete authority for the hearing and their final decision is binding to both parties. To make the decision binding to both parties, the arbitration process is supported by court judgment. The arbitration ruling in the matter is unlikely to be revoked except in cases of fraud, corruption, arbitrator misconduct, prejudicing the rights of a party, or refusal to hear evidence [36].

There are also distinct features of arbitration that differentiate it from litigation. Arbitration hearings are 
private and are only attended by the arbitrators and the disputants. Other parties may attend the hearing but only with the approval of the arbitrators and the disputants [29]. In contrast to litigation, almost any evidence is accepted in arbitration, however, arbitrators should pay extreme attention to the weight they assign to any evidence [22, 29]. Arbitration hearings usually do not need expert witnesses, in contrast to court judges, are customarily expert in their fields $[22,30]$. The procedures of arbitration are flexible and give the disputants some sort of control in the selection of the arbitrators [37]. These arbitrators are often knowledgeable and qualified in the construction projects. The arbitration proceedings are private and less time consuming, which gives this method extra advantages [22, 30, 37-39]. Finally, disputants who desire to maintain a good relationship after resolving the dispute are recommended to seek arbitration [22, 30, 37, 39-41].

Arbitration, however, is not always the perfect option that has no defects. In recent years, the informality of the process has begun to change; arbitration is now transforming into a structured, more elaborative and more expensive process than before. This makes arbitration loses its advantages over litigation. The process is not also guaranteed to run smoothly; it is subject to constant delays caused by scheduling conflicts between the parties and the arbitrators [33, 34]. The arbitration decision could be overturned if the law is not strictly followed [21, 34], but this is the case in litigation. In general, today there is a disagreement among authors about the effectivity of litigation as a speedy and more economical method to disputes resolution [42].

\subsection{Mediation}

Mediation is considered as a structured, informal and nonbinding negotiation and it is believed to be the most important method of ADR [23]. Moreover, it is believed that mediation is the fastest-growing ADR method in construction industry [43-45]. The negotiation process is guided by a neutral and impartial third party adviser, called the mediator, who listens to both parties of the dispute and facilitates negotiations between the disputants $[38,46-48]$. The most important phase in mediation is the initial stage where each party tells their perception of the dispute. The mediator then tries to establish a rapport with the disputants. The mediator then tries to minimize the differences and to bring the disputants perceptions closer in attempt to solve the dispute $[47,49]$.

The mediation decision could be voluntary or initiated by a court order. However, mediation is not binding, and the dispute cannot be resolved in anyhow but only by mutual agreement [50]. There is a disagreement in the literature about the role of the mediator in the process. Some studies consider offering an opinion by the mediator a disruption of the process and that a good mediator should only guide and facilitate the mediation in an attempt to reach a mutual agreement [38, 43]. Another study believes that the disputants head to the mediator seeking his evaluation of their current dispute. The study also found that more than $70 \%$ of disputants who seek mediation think that mediators should state their opinions upon the request of the disputants [51, 52]. Mediation is an affordable, confidential, and satisfactory way to resolve disputes $[38,51]$. It also improves understanding the roots of the dispute between the parties and the presence of an impartial mediator helps in softening the troubled relationship between the disputants. Mediation is highly recommended when trust and future relationships are to be maintained between disputants [49]. Mediation is also favourable because all dispute matters are discussed face to face rather than through attorneys or other intermediaries; this makes the disputants feel that they are in control of the resolution process [53]. Mediation is also believed to be successful because the settlement is reached by the disputants themselves; this should encourage them to honor the guides of the agreement [30].

Mediation could become a tiresome process in complicated projects that result in intertwining disputes. In completed situations, the mediator fails to bring the parties to a mutual agreement that satisfies all of them. Moreover, since mediation is not binding, and the respect of the agreement depends on the intentions of the parties, the process might be stopped suddenly and wasting all the time and efforts used in mediation. Mediation in some courts is obligatory to enter into arbitration or litigation, therefore, it could be used to stall court proceedings. The highest concern in mediation is that if an agreement is not reached, nothing can force a solution for the dispute [30, $38,43,49]$.

\subsection{MEDIARB}

The med/arb method is a hybrid of mediation and arbitration that was developed by the Associated Soil and Foundation Engineers (ASFE) in the 1970s. It combines mediation, a conciliatory process, with arbitration, an adversarial process. Firstly, mediation is started and if disputes are not settled, arbitration is used $[54,55]$. The $\mathrm{med} / \mathrm{arb}$ method can be thought of as a binding mediation. If this method is selected to resolve disputes, a neutral party should be selected by the contract parties at the start of the project. This method aims to manage and resolve disputes immediately as they arise and ultimately, the decision of this process will be binding [56].

The advantage of this hybrid over other ADR methods is that it enhances reaching a solution during the mediation stage because both parties are unlikely to be favoured going into arbitration, which is a must in case mediation fails. While the parties have control over manners in mediation, they lose such a control in the arbitration stage.

The use of this hybrid method however, is still opposed by many experts. This mainly due to the fact that the neutral party during mediation is improbable to remain unbiased during the arbitration stage after knowing much confidential information during mediation. Moreover, since the parties know that there is a possibility of going into arbitration, they might tend to hide information that might otherwise be revealed if only mediation is used [54, 56]. 


\subsection{Mini-trial}

The mini-trial is an alternative dispute resolution procedure that is used in construction industry to resolve disputes without incurring the expense and delay associated with court litigation. The term mini-trial may be misleading; a mini-trial is different from an actual trial in being a voluntary and non-binding process, but like trials, the process is still adversarial. It is a structured settlement procedure that treats the dispute more as a business problem, rather than a legal one $[57,58]$. The parties pay an equal share of the mini-trial costs [48]. The mini-trial does not result in a formal binding decision, but it is considered a vehicle to arrive the parties to a solution. It is effective when complex issues are at stake and the parties need or wish to maintain a friendly relationship. Therefore, a mini-trial will put all the parties in perspective of what is going to happen if they actually head to trial.

The mini-trial uses elements of negotiation and mediation to facilitate the settlement. Parties are exposed in the nonbinding mini-trial to the theories, strengths, and weaknesses of each side of the controversy. The main goal of the mini-trial process is to predict the results of an actual trial, thereby enabling the parties to come to a business decision to resolve their dispute. Hence, minitrials are usually held after other mechanisms of solving disputes have failed, but before going into litigation [59, $60]$. The mini-trial is considered effective in complex situations where all other methods have failed, but still, the parties want to maintain a good relationship. The pain points of using mini-trial are the possibility of revealing trial tactics and the additional expenses and delay if litigation is ultimately needed.

\subsection{Dispute Review Boards (DRB)}

The dispute review board (DRB) becomes a contractual requirement. It is considered an innovative nonadversarial project management technique for avoiding or resolving disputes during the project lifecycle. This method attempts to prevent disputes before they even arise. This method differentiates itself from other ADR methods because it pursues a procedure that tries to mitigate disputes and to deal with them immediately as they arise [61]. The DRB consists of a three-member panel chosen and approved jointly by the parties prior to the start of the project. All parties must have complete confidence in the DRB's integrity and impartiality for this process to be effective [62]. After the panel is chosen a third-party agreement is executed by the panelists and the project parties. This agreement establishes the parties purpose, scope of work, responsibilities, duration of the agreement, payment for services, and termination of panelists. Essentially this agreement is the formal mechanism that defines the parties' responsibilities to each other and the remuneration the panelists will receive for their services. The duration of the panel's engagement is specified in the agreement. In most cases, it is for the entire duration of the project, but it can be terminated with or without cause or on mutual agreement.
The DRB regularly visits the project, but should the need arise it could also convene at times of critical construction events or based on the request of the parties $[34,63]$. The frequency of job site visits depends on the nature of the work as well as the number of potential or actual disputes [64]. To keep current with the development and progress of the project, the DRB is informed of construction activity via regular written progress reports, meetings, and other relevant documents forwarded by project parties. A major strength of the DRB is its familiarity with the ongoing construction and any important developments on the project [8]. By visiting the project on a regular basis, the DRB acquires an intimate knowledge of the difficulties the parties encounter and can make recommendations to resolve conflicts before they escalate into disputes [65].

The owner or the contractor can request a hearing to present an unresolved conflict to the DRB. A dispute should be brought to the DRB as soon as the parties have determined that a negotiated settlement is unlikely, but only after exhaustion of the dispute resolution procedure as detailed in the contract documents. The contract generally outlines the steps a contractor must take in its efforts to resolve a dispute before presenting it to a DRB for their recommendations. These steps include the formal submission of a change-order request, which includes a justification of the request along with any costs or time extensions sought. This initial change-order request is followed by questions or comments by the owner that generally include a give and take regarding what information is sought or provided in the negotiation of the change order [66]. The hearings are informal and "focus on the issues in dispute". At the hearing itself, each party is given a reasonable opportunity to present its case. The parties are required to have representatives with direct knowledge of the problem at the hearings. This allows the DRB panelists to question individuals with first-hand knowledge of the problem being heard [8, 63, 64].

After the close of the hearing and all requested information or documentation has been received, the DRB issues a comprehensively written finding as to how it believes the dispute should be resolved. The decision time to accept or reject the recommendation is either noted in the specifications or determined by the rules of procedures mutually agreed to at the initial meeting. According to statistics maintained by the Dispute Resolution Board Foundation, DRBs currently achieve a $98 \%$ success rate, as all conflicts and disputes resolved prior to contract completion $[8,63,64]$.

Based on the above discussion of the traditional dispute resolution methods and the alternative dispute resolution (ADR) methods, disputes should be addressed by prevention, in the early stage of the project planning and the well prepared and defined project scope. To successfully prevent disputes in construction projects, it is vital to understand the particulars of the specific project. However, disputes still can appear during the project lifecycle should be settled first internally without any external intervention. Therefore, the vast majority of disputes are resolved by internal negotiations. Where interparty negotiations fail, construction contracts commonly offer the parties many options. In this regard it 
may be prudent to involve an impartial third party, i.e., a dispute review board, throughout the life of the construction project. Such a dispute review board adds value by assisting the parties in the development of applicable dispute prevention techniques. Next is to seek dispute resolution through third parties, usually by way of litigation or arbitration. The escalation of hostility, control level and costs as a result of moving to higher levels in the hierarchy of disputes, in the form of rising steps is shown in Figure 1 below.

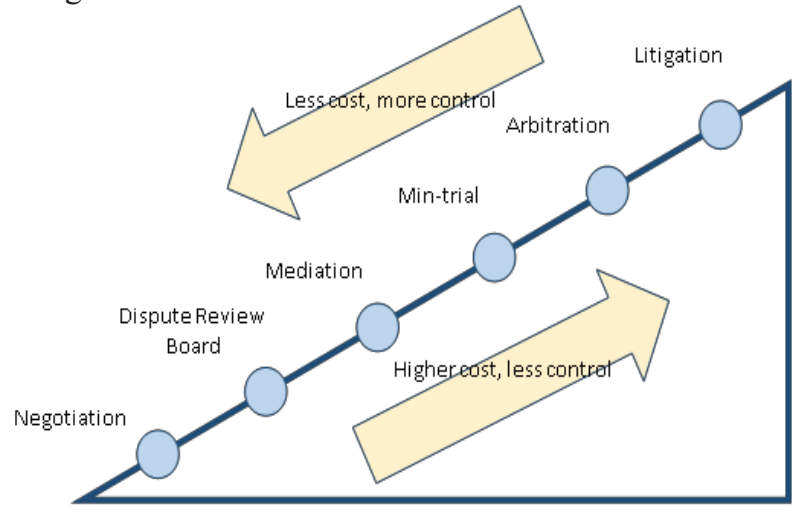

Fig. 1. A summary of dispute resolution process.

A win-win situation is usually an aim of each party in a conflict but when disputes go into litigation a win-win situation will be very unusual. A lose-win situation will be the outcome, or even a lose-lose situation in some cases, due to wasted time and the cost of lawyers. At the same time lawyers competent in engineering issues or engineers with legal backgrounds are difficult to find.

\section{Conclusion}

Resolving disputes that arise in the construction industry can be accomplished using several methods. However, there is no best way of resolving disputes that is suitable for all cases. It is important for both owners and contractors to be knowledgeable of the advantages and disadvantages of each method, and to ensure that contracts which they enter into contain appropriate dispute resolution clauses. This paper describes several dispute resolution methodologies used in construction projects, the most widespread of which are litigation and arbitration, with mediation quickly gaining in acceptance. It has also reviewed other ADR processes, such as med/arb, mini-trials, and dispute review boards. Each process has positive and negative features depending on the law, facts, time, and cost. The difficulty in deciding which methodology best suits a party's needs depends on the dispute, the contractual parties' relationship, and other factors. Yet many times the conflict resolution methodology is chosen prior to the occurrence of a dispute when it is included in the contract. The contractual dispute resolution methodology may not be the best one once dispute have arisen, so flexibility in what mechanism is actually utilized should be, but is often not, adaptable.

\section{References}

1. W. S. Alaloul, et al. Industry Revolution IR 4.0: Future Opportunities and Challenges in Construction Industry. in MATEC Web of Conferences. (2018). EDP Sciences.

2. B. K. Pétursson, Disputes and Conflicts within Construction Contracts in the Icelandic Construction Industry. (2015).

3. S. Hasanzadeh, et al., Impact of Owners' Early Decisions on Project Performance and Dispute Occurrence in Public Highway Projects. Journal of Legal Affairs and Dispute Resolution in Engineering and Construction, (2018). 10(2): p. 04518004.

4. W.S. Alaoul, M.S. Liew, and N.A.W.A. Zawawi, Identification of coordination factors affecting building projects performance. Alexandria Engineering Journal, (2016). 55(3): p. 2689-2698.

5. B. A. Tayeh, et al., Factors Affecting the Success of Construction Projects in Gaza Strip. The Open Civil Engineering Journal, (2018). 12(1).

6. P. Campbell, Construction Disputes: Avoidance and Resolution. (1997): Whittles Publishing.

7. W. S. Alaloul, M.S. Liew, and N. Zawawi, Coordination process in construction projects management, in Engineering Challenges for Sustainable Future. (2016), ROUTLEDGE in association with GSE Research. p. 149- 153.

8. K. M. Harmon, Dispute review boards and construction conflicts: Attitudes and opinions of construction industry members. (2004)

9. W. S. Alaloul, M. S. Liew, and N. A. W. A. Zawawi. The characteristics of coordination process in construction projects. in Technology Management and Emerging Technologies (ISTMET), 2015 International Symposium on. (2015) IEEE.

10. W. S. Alaloul, et al., Delphi Technique Procedures: A New Perspective in Construction Management Research. Applied Mechanics \& Materials, (2015). 802.

11. N. K. Acharya, Y. Dai Lee, and H. Man Im, Conflicting factors in construction projects: Korean perspective. Engineering, construction and architectural management, (2006). 13(6): p. 543-566.

12. C. Cobuild, Collins Cobuild english dictionary. (1995), London: HarperCollins.

13. W. W. Wilmot, and J.L. Hocker, Interpersonal conflict. (2001): McGraw- Hill New York.

14. J.E. Diekmann, and M. J. Girard, Are contract disputes predictable? Journal of construction engineering and management, (1995). 121(4): p. 355363.

15. P. Fenn, D. Lowe, and C. Speck, Conflict and dispute in construction. Construction Management \& Economics, (1997). 15(6): p. 513-518.

16. W. S. Alaloul, M.S. Liew, and N.A.B. Zawawi. A Framework for Coordination Process into Construction Projects. in MATEC Web of Conferences. (2016). EDP Sciences.

17. T. J. Stipanowich, Reconstructing construction law: Reality and reform in a transactional system. Wis. L. Rev., (1998): p. 463. 
18. Alaloul, W.S., M.S. Liew, and N.A.W. Zawawi. Communication, coordination and cooperation in construction projects: business environment and human behaviours. in IOP Conference Series: Materials Science and Engineering. (2017). IOP Publishing.

19. M. Green, Construction Adjudication and the Definition of Disputes: an Analysis of Recent Case Law. in Proceedings of the 2006 COBRA conference, Bartlett School, UCL, London. (2006).

20. W. S. Alaloul, M.S. Liew, and N.A.W.A. Zawawi, Journal of Applied Science and Agriculture.

21. M. O. Rendell, $A D R$ versus litigation. Dispute Resolution Journal, (2000). 55(1): p. 69.

22. J. Tolle, W. Barton, and M. Mountain, 'Construction arbitration procedures, edition II. Construction Briefings, (1990). 12.

23. W. Hughes, R. Champion, and J. Murdoch, Construction contracts: law and management. (2015): Routledge.

24. J. C. Kellogg, The contract disputes resolution continuum. (1992): Kellogg Corporation.

25. D. Arditi, F.E. Oksay, and O.B. Tokdemir, Predicting the outcome of construction litigation using neural networks. Computer-Aided Civil and Infrastructure Engineering, (1998). 13(2): p. 75-81.

26. H. L. Meyer, Can't Wait to Try Your Case-Think Twice. ABAJ, (1984). 70: p. 72.

27. D. Bristow, and R. Vasilopoulos, The new CCDC 2: facilitating dispute resolution of construction projects. Construction Law Journal, (1995). 11: p. 95-95.

28. W. E., Burger, Isn't there a better way. ABAj, (1982). 68: p. 274.

29. Currie, O. and R. Robey, 'Winning strategies in construction negotiations, arbitration, and litigation. (1988), Wiley, New York. p. 911-960.

30. T. L. Trantina, An Attorney's Guide to Alternative Dispute Resolution (ADR):" ADR 1.01". 2003.

31. S. Pinnell, Partnering and the management of construction disputes. Dispute Resolution Journal, (1999). 54(1): p. 16.

32. S.-O. Cheung, Critical factors affecting the use of alternative dispute resolution processes in construction. International Journal of Project Management, (1999). 17(3): p. 189-194.

33. T. J. Stipanowich, At the cutting edge: conflict avoidance and resolution in the US construction industry. Construction Management \& Economics, (1997). 15(6): p. 505-512.

34. T. B. Treacy, Use of alternative dispute resolution in the construction industry. Journal of Management in Engineering, (1995). 11(1): p. 58-63.

35. R. Coulson,, Business arbitration--what you need to know. (1991): American Arbitration Association.

36. T. J. Heinsz, The Revised Uniform Arbitration Act: An Overview. Dispute Resolution Journal, (2001). 56(2): p. 28

37. D. M. Mix, ADR in the construction industry: continuing the development of a more efficient dispute resolution mechanism. Ohio St. J. on Disp. Resol., (1996). 12: p. 463.
38. P. Gillie,, et al., 'Using mediation to resolve construction disputes. (1991), Wiley Law, New York. p. 153-210.

39. K. Phillips, 'Arbitration or litigation? From the Ground Up, (1999): p. 4-5.

40. M. Gillie, 'Litigation and America's competitiveness: It's time for a change.'. USA Today, (1988): p. 33-35.

41. P. Levine, 'Resolving construction disputes outside the courtroom. New Jersey Building Contractor, (2000). 1: p. 30-32.

42. M. S. Abdullah, et al. Delays and Cost Overruns Causes During Construction of Palm Oil Refinery Projects. in MATEC Web of Conferences. (2018). EDP Sciences.

43. D. R. Goodkind, Mediation of construction disputes. Journal of performance of constructed facilities, (1988). 2(1): p. 9-12.

44. I. R. Macneil, R.E. Speidel, and T.J. Stipanowich, Federal arbitration law: agreements, awards, and remedies under the Federal Arbitration Act. Vol. 2. (1994): Little, Brown.

45. R.C. Reuben, The lawyer turns peacemaker. ABAJ, (1996). 82: p. 54.

46. A. Ashworth, Contractual procedures in the construction industry. (2006): Pearson Education.

47. K. Harmon, Mediation: Satisfaction in the process and outcome. Construction Briefings, 2002. 6.

48. M. Loulakis, and R. Smith. 'Alternative means of construction dispute resolution-A brief description and contract document implications. in National Conf. of Construction Management Association of America. (1992).

49. C.W. Moore, The mediation process: Practical strategies for resolving conflict. (2014): John Wiley \& Sons.

50. B.A. Phillips, Mediation: did we get it wrong. Willamette L. Rev., (1997). 33: p. 649.

51. T.J. Stipanowich, Beyond arbitration: Innovation and evolution in the United States construction industry. Wake Forest L. Rev., (1996). 31: p. 65.

52. W.S. Alaoul, et al., An Artificial neural networks (ANN) model for evaluating construction project performance based on coordination factors. Cogent Engineering, (2018) 5(1) :p. 1-18.

53. R.A.B. Bush, and J.P. Folger, The promise of mediation: The transformative approach to conflict. (2004): John Wiley \& Sons.

54. J.R. Cheeks, Multistep dispute resolution in design and construction industry. Journal of Professional Issues in Engineering Education and Practice, (2003). 129(2): p. 84-91.

55. E.J. Costello Jr, ADR: virtue or vice? Dispute Resolution Journal, (1999). 54(2): p. 62.

56. T.J. Stipanowich, Contract and conflict management. Wis. L. Rev., (2001): p. 831.

57. J.F. Henry, ADR and construction disputes: the minitrial. Journal of performance of constructed facilities, (1988). 2(1): p. 13-17.

58. Prevention, U.o.T.a.A.C.I.I.D., et al., Dispute Prevention and Resolution Techniques in the Construction Industry. (1995) : Institute, University 
of Texas.

59. A. Goodman, General services administration board of contract appeals extend to ADR-An overview. The Construction Contractor, (1997). 21(9): p. 3-6.

60. W. Alaloul, M. Liew, and N. Zawawi. Attributes of coordination process in construction projects. in Engineering Challenges for Sustainable Future: Proceedings of the 3rd International Conference on Civil, Offshore and Environmental Engineering (ICCOEE 2016, Malaysia, 15-17 Aug 2016). (2016). CRC Press.

61. P. Chapman, Worldwide application of the DRB method of dispute resolution. in Proc., Institution of Civil Engineers Mid-Atlantic States Local Association and World Bank Conf. on Dispute Review Boards. (2001).

62. E.K. Zaneldin, Construction claims in United Arab Emirates: Types, causes, and frequency. International Journal of Project Management, (2006). 24(5): p. 453-459.

63. J.D. Coffee, Dispute Review Boards in Washington State. Arbitration Journal, (1988). 43(4).

64. R.A. Shadbolt, Resolution of Construction Disputes by Disputes Review Boards.

International Construction Law Review, (1999). 16: p.101-111.

65. N. A. Zawawi, and A. Abdullah, Evaluating stakeholders preferences: reconciling heritage and sustainability. WIT Transactions on Ecology and the Environment, (2011). 150: p. 675-686.

66. W.A. Zawawi, et al., Sustainable construction practice: A review of Change Orders (CO) in Construction Projects. (2010). 